ارتباط رطوبت و سرب موجود در خاك بر فعاليت آنزيمهاى اورهآز و فسفاتاز خاى

اكبر فرقانى ".، امير حسين فرقانى"، معصومه تقىزاده" و بابك ربيعى"

(تاريخ دريافت:

جكيده

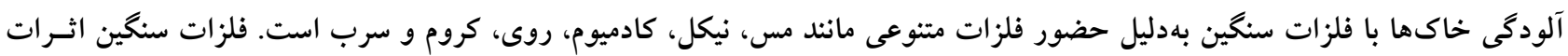

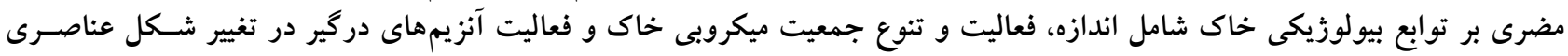

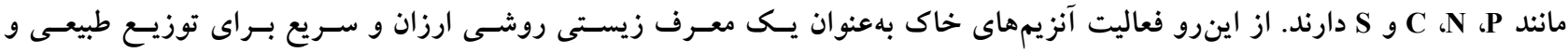

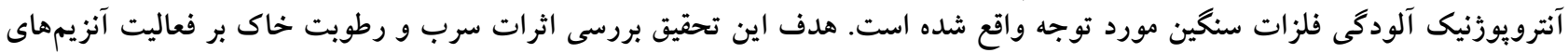

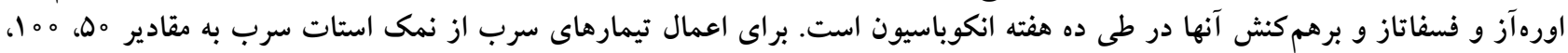

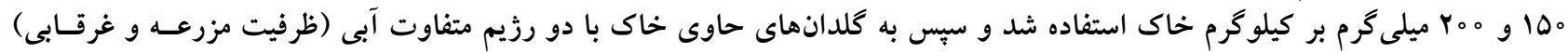

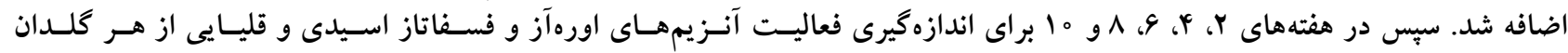

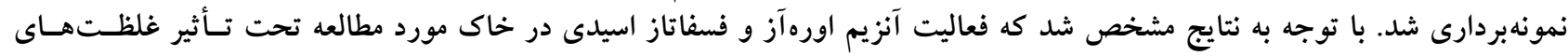

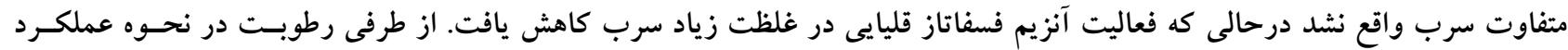

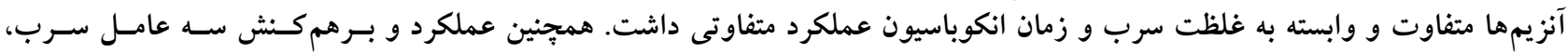

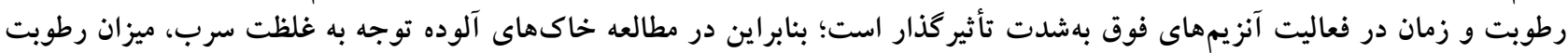

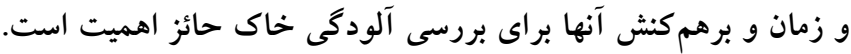

وازمهاى كليدى: خصوصيات فيزيكى و شيميايى خاك، ظرفيت مزرعه، غرقاب، فسفاتاز اسيدى، فسفاتاز قليايى

ا-كروه خاكشناسى، دانشكده كشاورزى، دانشگاه رشت، رشت

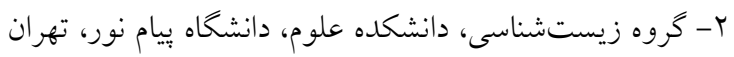

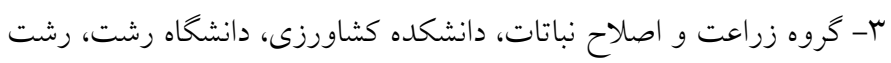

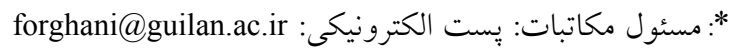




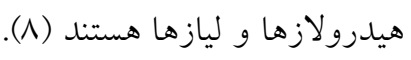

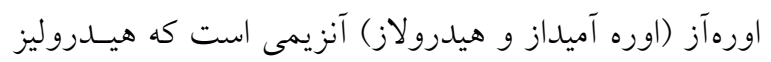

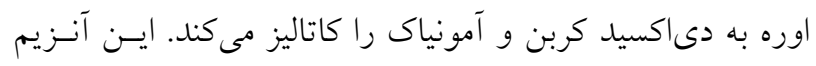

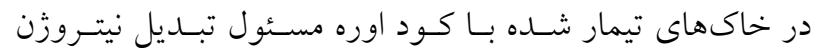

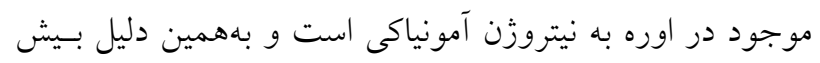

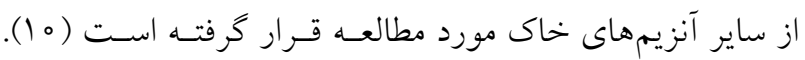

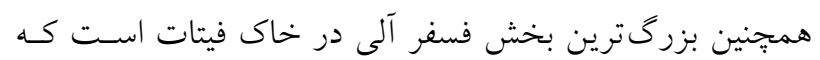

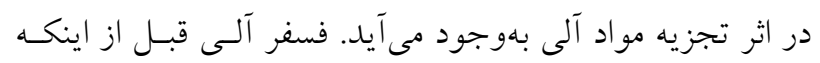

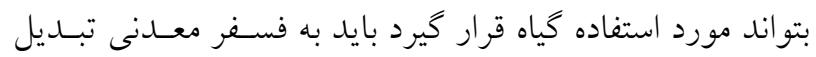

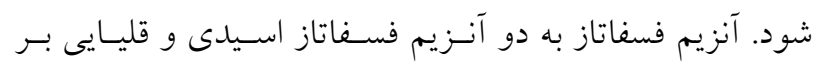

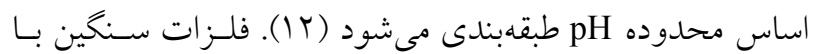
ايجاد كميلكس از طريق اتصال بـهـ كـروههـاى فعـال يروتئينى

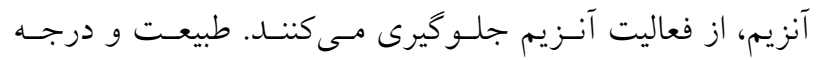

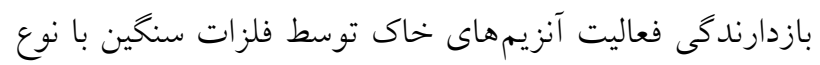

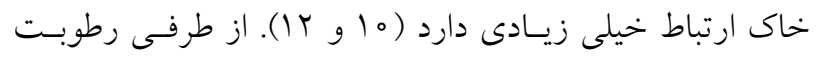

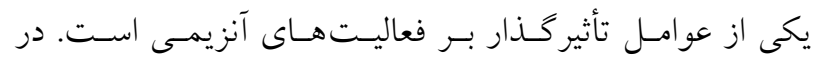

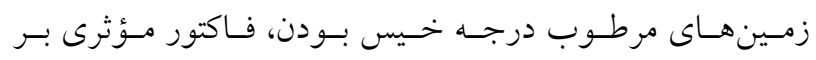

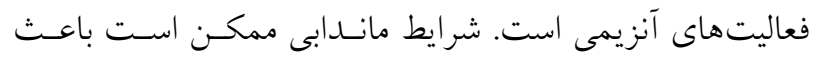

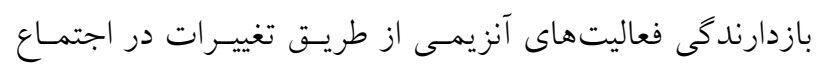

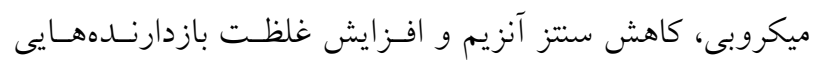
مانند Fe تحت شر ايط احيا شود (V)،

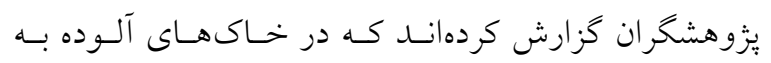

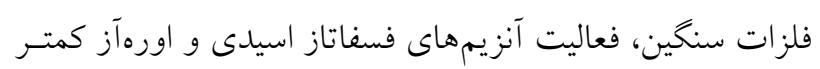

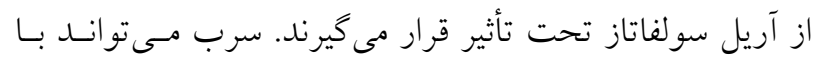

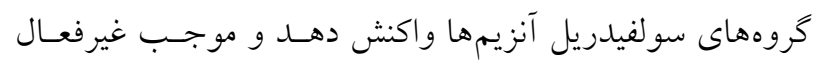

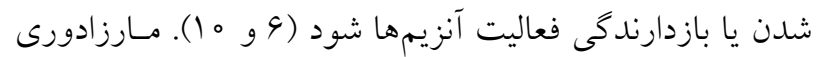

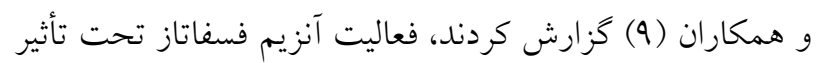

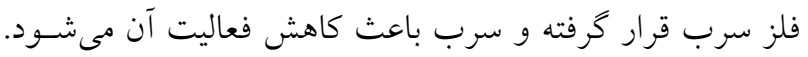

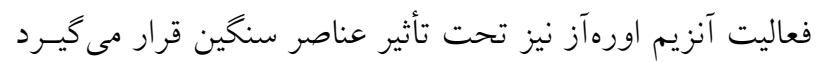

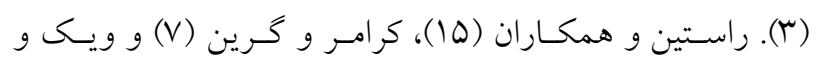
همكاران (YY) نشان دادهاند، تغييرات فصلى در رطوبـت خـاك فراك

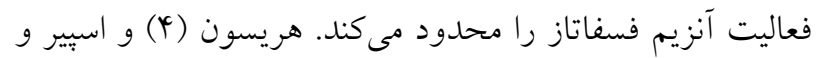

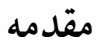

فلزات سنخين بهعنوان يكى از مهم ترين منابع خـاكهـاى آلـوده

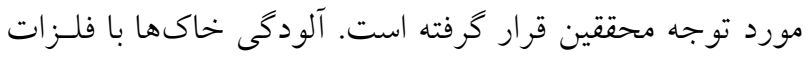

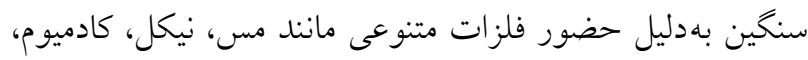

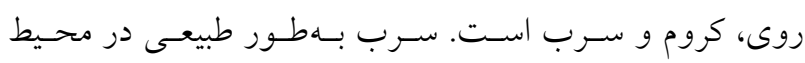

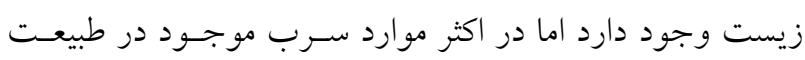
حاصل فعاليتهاى انسانى است و يكى از متداولتسرين فلـزات

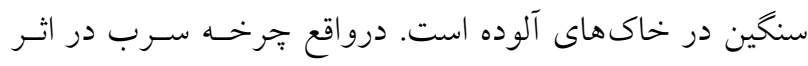

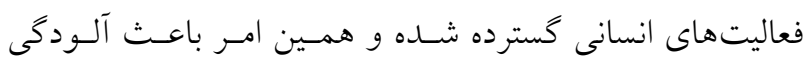

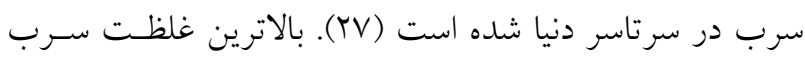

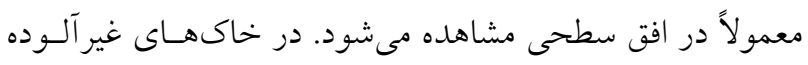

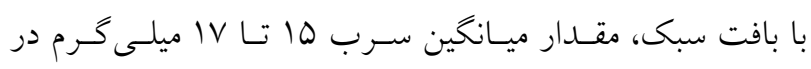

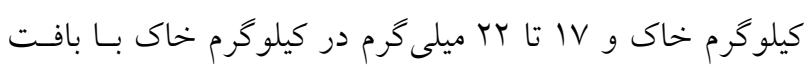

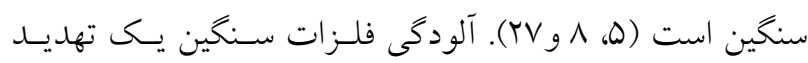
جدى براى كيفيت خاى محسوب مىشود زيرا فلـزات سـنخين

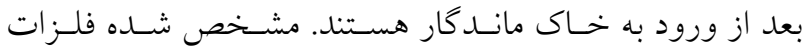

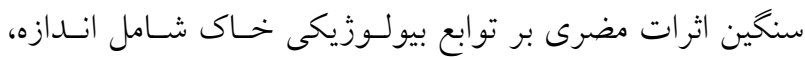

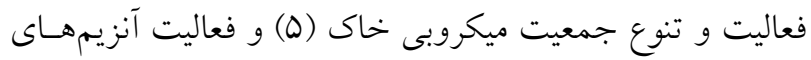

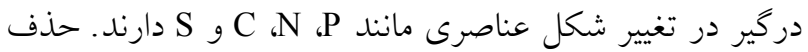

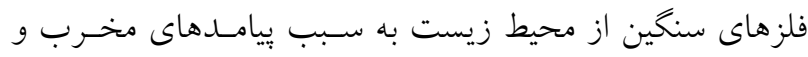
درازمدت آن مورد توجه قرار كرفته است. از ايـنرو اسـتفاده از يكى فناورى كارآمد و دوستدار محسيط زيستـت بـراى كنتـرل

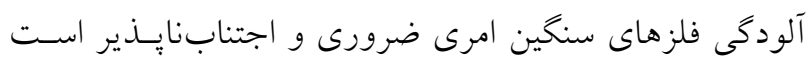

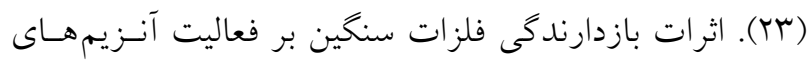

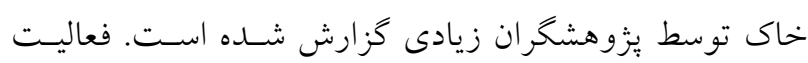

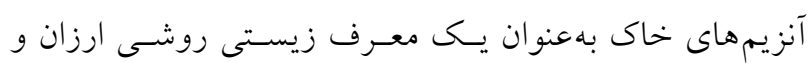

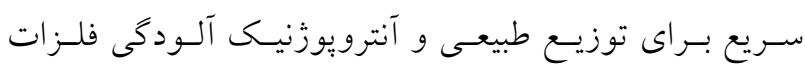

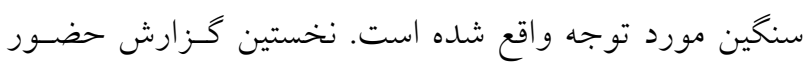
آنزيم در خاك مربوط به سال 1991 ميلادى، يعنى قبل از آغاز

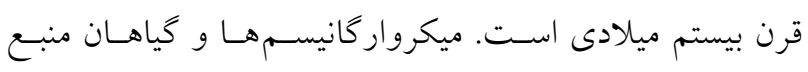

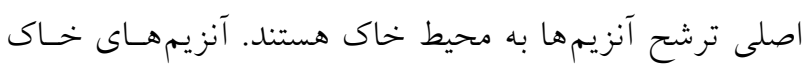

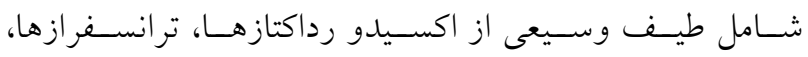


غرقاب انجام شد، خاك هر كلدان، ابتـدا در پِلاسـتيك ريختـهـ

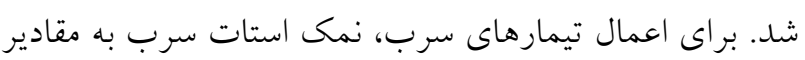

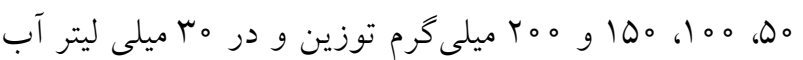

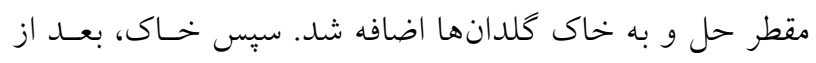

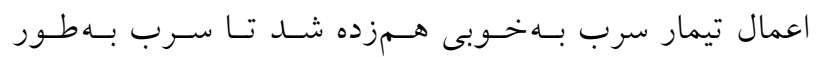

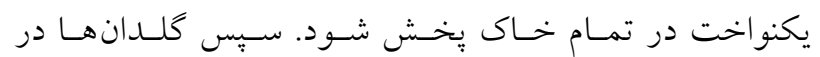
رطوبت مورد نظر تنظيم شدند بهطورى كه براى اعمال تيمـار

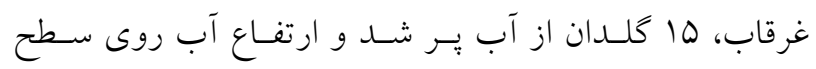

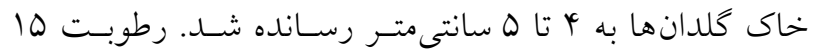

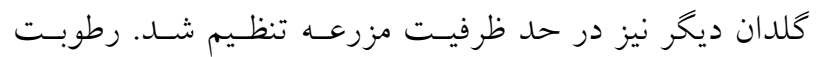

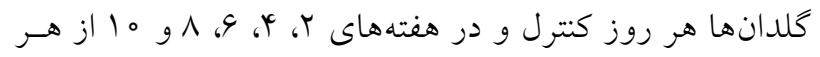
كلدان نمونهبردارى براى اندازه گيرى فعاليت آنزيمهاى اورهآ رآز

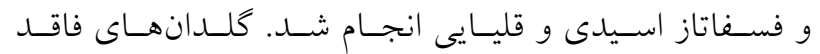

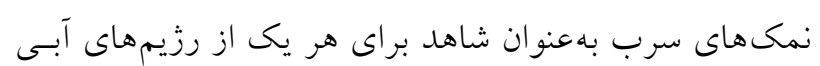

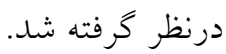

اندازهيرى مقدار فلـزات خــاك بـا روش هضــم در اسـيد نيتريك جهار مولار

بهمنظور تعيين غلظت كل عنصر سرب و آهن، نمونهاى خـاك هولاى

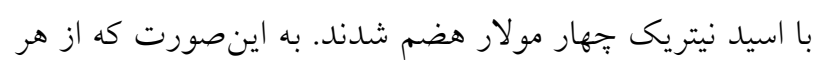

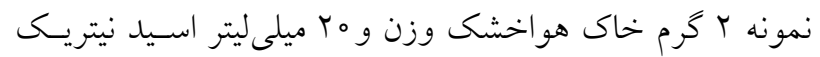

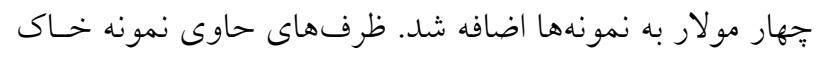

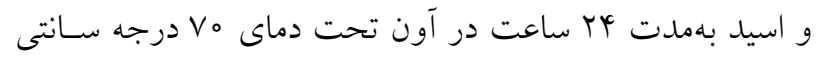

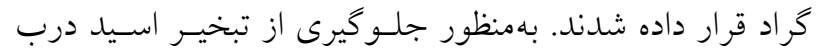

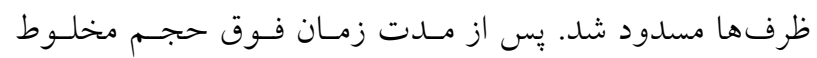

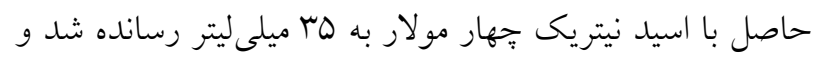

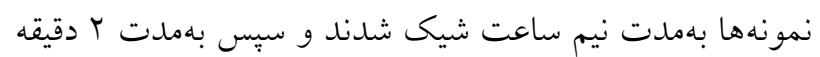

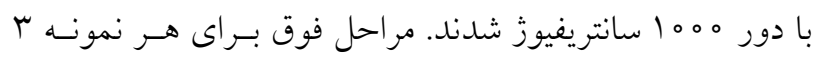

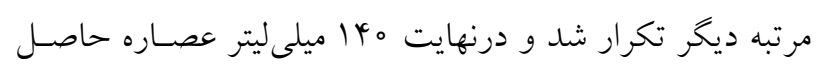

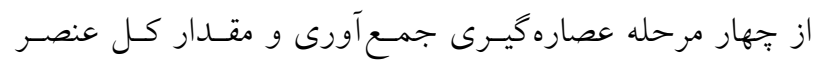

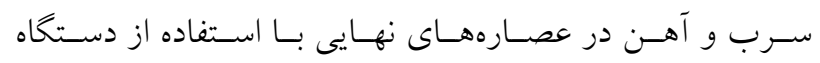

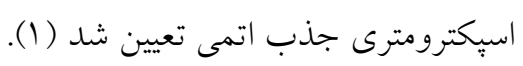

همكاران (1) كزارش كردهاند كه فعاليـت فسـفاتاز همبسـتخى

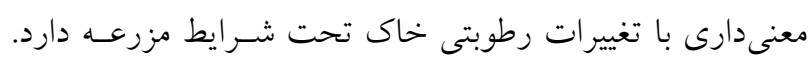

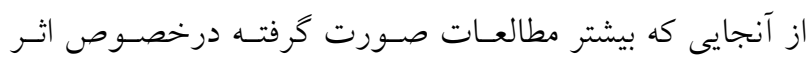

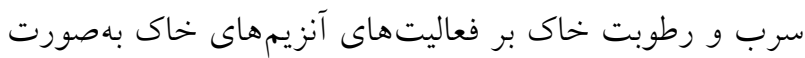

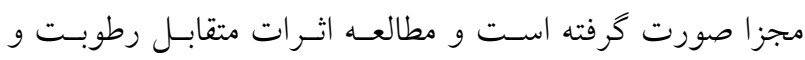

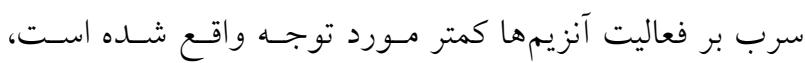

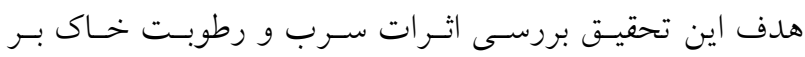

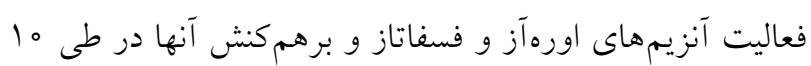

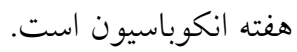

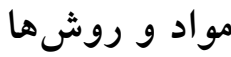

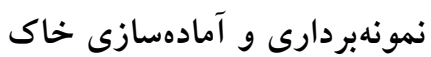

با توجه به اينكه خاك مورد آزمايش حتى المقــدور بايســ داراى بافت متوسط و مقدار سرب در حد بايين باشد، لذا بهمنظور بيدا

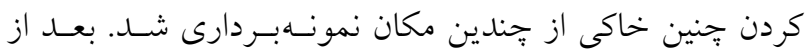

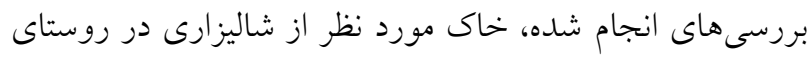

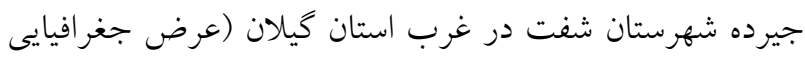

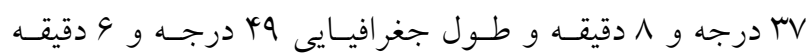

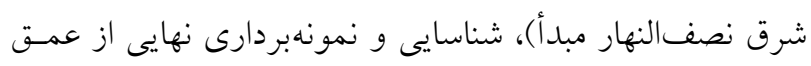

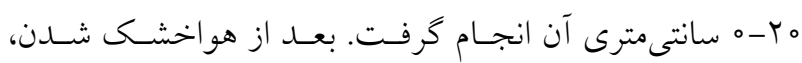

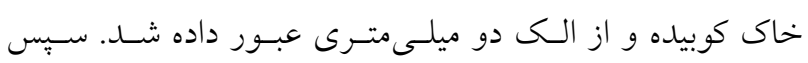

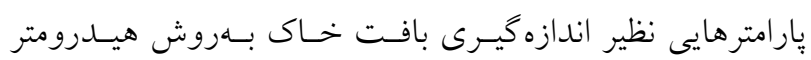

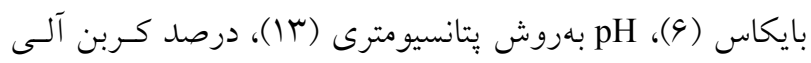

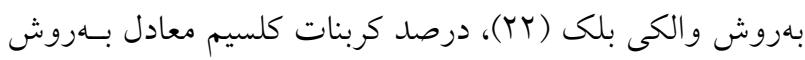

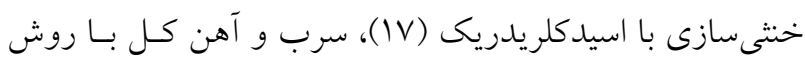

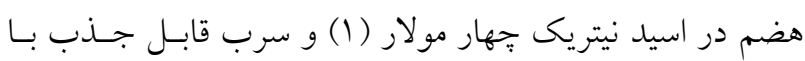
روش DTPA (19) و ظرفيت تبادل كاتيونى با روش جايخزينى

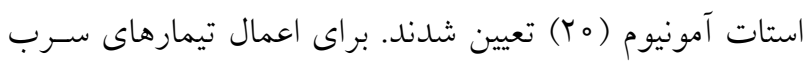

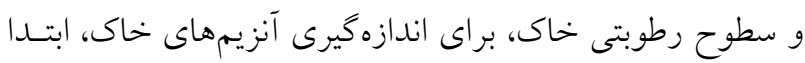

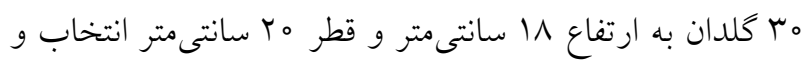

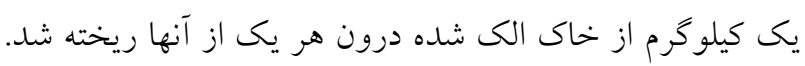

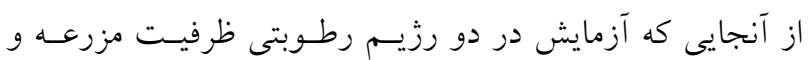


آن افزوده شد. به ارلنهاى شاهد يكى ميلىليتر مححلـول بسـتره

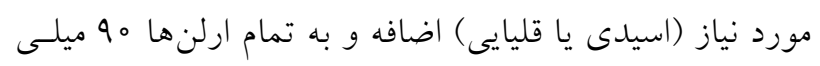

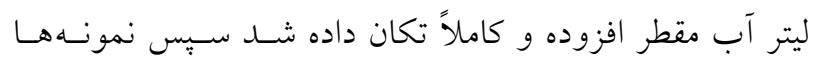

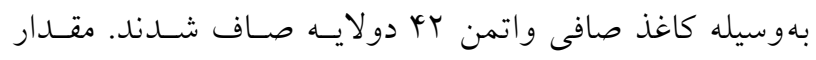

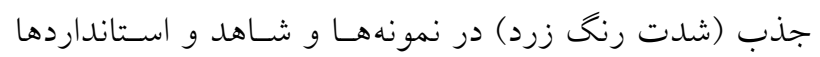

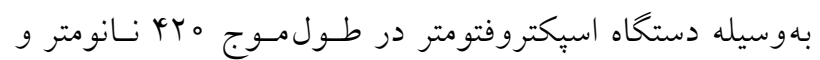

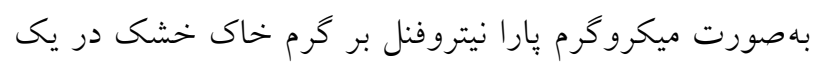
سـاعت انكوباسـيون (

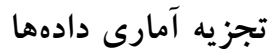
براى تجزيه واريانس دادهها، از طرح آمارى، فاكتوريل - اسيليت

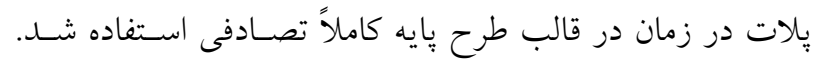
غلظتهاى سرب و وضعيت رطوبتى خاك بهصورت فاكتوريـل

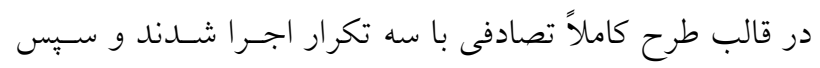

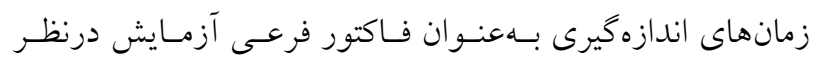

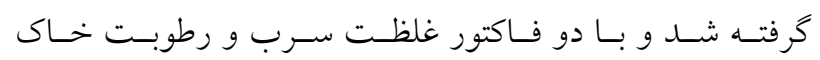

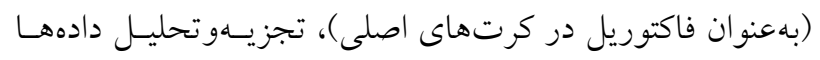

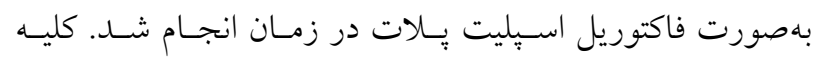

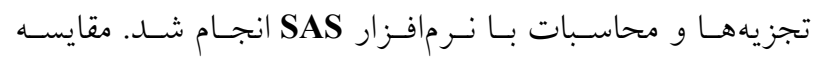

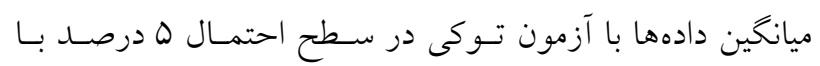

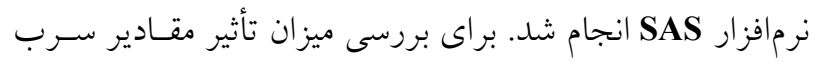

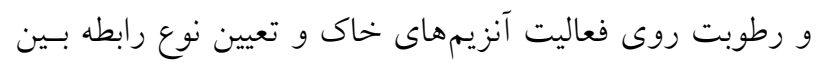

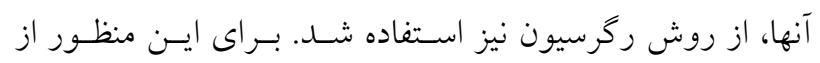

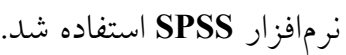

\section{نتايج}

\section{خصوصيات فيزيكى و شيميايى خاك مورد آزمايش}

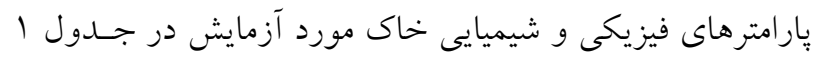

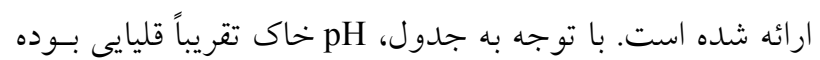

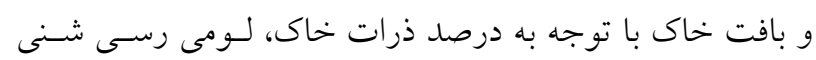

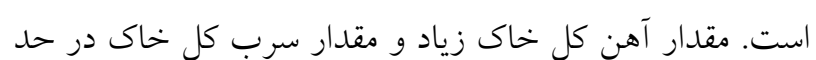

اندازهگيرى فعاليت آنزيم اورهآز

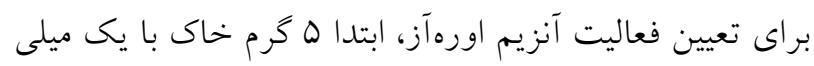

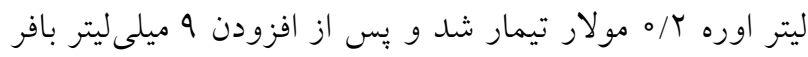

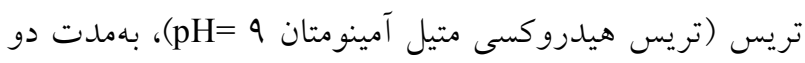

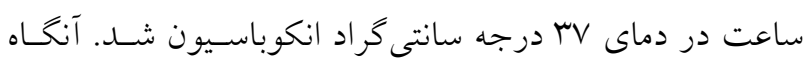
هr ميلى ليتر محلول KCl-Ag

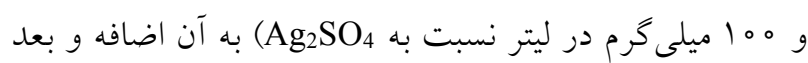
از خنك شدن، با اضافه كردن محلول KCl-Ag2

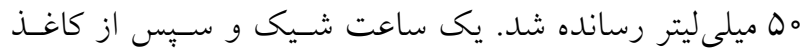

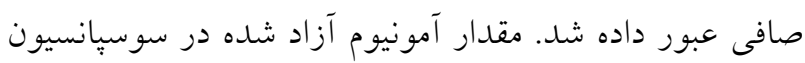

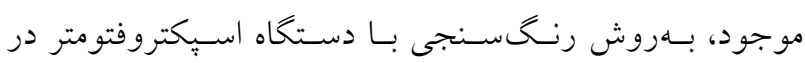

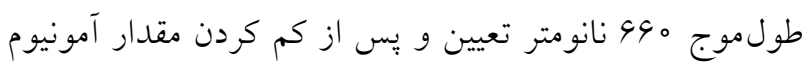

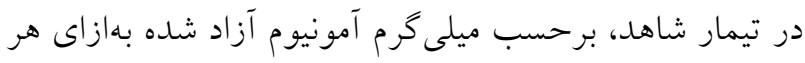

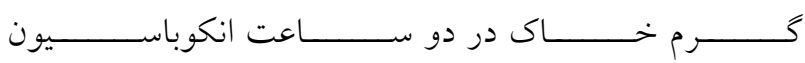
كزارش شد (19) (mg N-NH${ }_{4}^{+}$gr $^{-1}$ soil $\left.2 \mathrm{hr}^{-1}\right)$

اندازهيرى فعاليت آنزيم فسفاتاز (اسيدى و قليايى) با بستره دى سديم يارانيتروفنيل فسفات

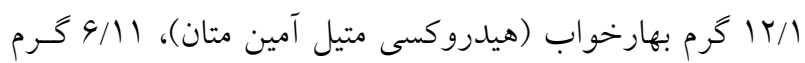

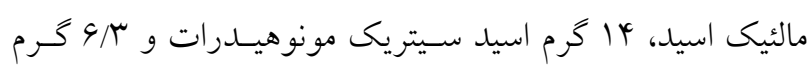

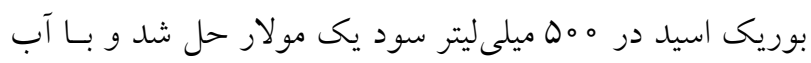

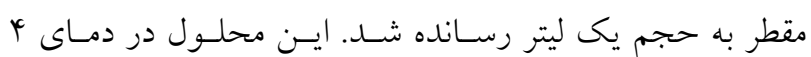

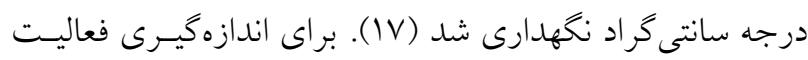

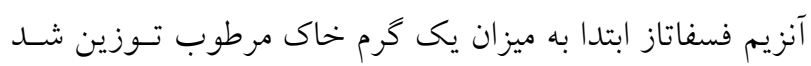

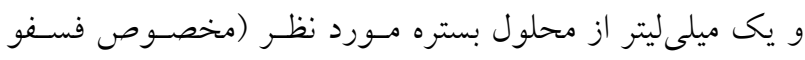

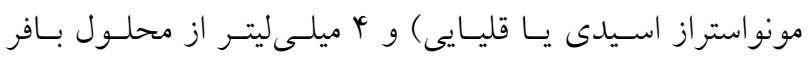

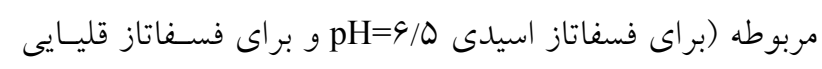

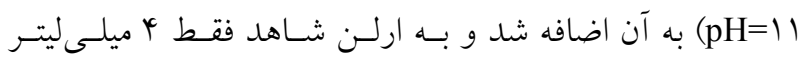

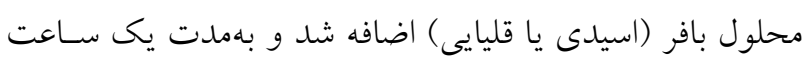

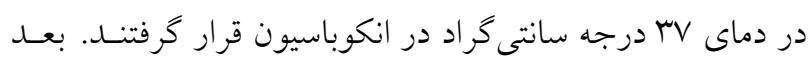

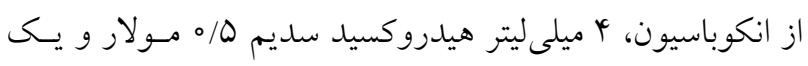

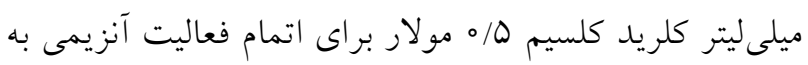


جدول ا. خصوصيات فيزيكى و شيميايى خاك مورد آزمايش

\begin{tabular}{|c|c|c|c|c|c|c|c|c|c|c|}
\hline $\begin{array}{c}\text { CEC } \\
\left(\text { meq 100gr }{ }^{-1}\right)\end{array}$ & $\mathrm{FC}$ & كربنات كلسيم معادل & كربن آلى & آهن كل & 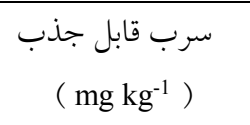 & سرب كل & & ) & & $\mathrm{pH}$ \\
\hline $1 / 19$ & $\Pi \Gamma / \Lambda T$ & $1 / 1 V$ & $1 / V$ & $r 4 / r q$ & $r / 11$ & $4 / \Lambda$ & 9 & 99 & 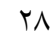 & $V / 40$ \\
\hline
\end{tabular}

جدول ז. خلاصه تجزيه واريانس اثر سرب و رطوبت بر فعاليت آنزيمهاى اورهآز و فسفاتاز اسيدى و قليايى خاك در طى زمان

\begin{tabular}{|c|c|c|c|c|}
\hline \multicolumn{3}{|c|}{ ميانخين مربعات } & \multirow{2}{*}{ درجه آزادى } & \multirow{2}{*}{ منابع تغييرات } \\
\hline آنزيم فسفاتاز قليايى & آنزيم فسفاتاز اسيدى & آنزيم اورهآز & & \\
\hline$\Delta Q / \circ \Delta^{* *}$ & $\circ / \wedge q^{\mathrm{ns}}$ & $\circ / \% q^{n s}$ & $r$ & 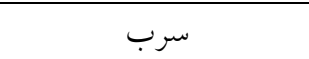 \\
\hline$V 9 V / 9 V^{* *}$ & $V Q / q Y^{* *}$ & $r Y / Y q^{* *}$ & 1 & ر روبت \\
\hline$G Y / \Delta \Gamma^{* *}$ & $10 / 19^{* *}$ & $\circ / \wedge \Delta^{\mathrm{ns}}$ & $r$ & سرب × رطوبت \\
\hline IN/Tr & T/VQ & $0 / 099$ & $r_{0}$ & خطاى اول \\
\hline$\Lambda \leftarrow \Lambda /\left.V\right|^{* *}$ & $V \Psi / \circ q^{* *}$ & $V \pi \omega^{* *}$ & $r$ & زمان \\
\hline $1 \mathrm{NV} / 99^{* *}$ & $\mu \varphi / \varphi_{0}^{* *}$ & $1 / \Lambda r^{* *}$ & $r$ & زمان × رطوبت \\
\hline$r_{\circ} / \Delta \varphi^{* *}$ & $\varphi / \mu)^{*}$ &.$/ 09 r^{*}$ & 19 & سرب × زمان \\
\hline$\Gamma \Gamma / T q^{* *}$ & T/MHYns & $\circ / \Lambda \wedge r^{* *}$ & 19 & سرب × رطوبت ز زمان \\
\hline $9 / 91$ & $r / 0 \Delta$ &.$\% 01$ & ^。 & خطاى آزمايش \\
\hline $10 / 44$ & IN/9Y & $9 / 44$ & & ضريب تغييرات (درصد) \\
\hline
\end{tabular}

شرايط رطوبت ظرفيت مزرعـه، فعاليـت آنـزيم اورهآز از هفتـهـ

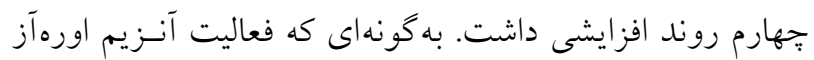
در هفته دهم انكوباسـيون در شــايط ظرفيـت مزرعـه اخـتلاف

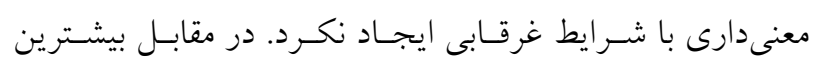

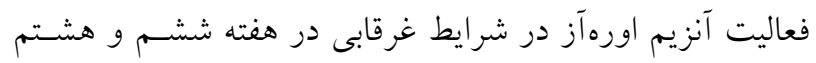

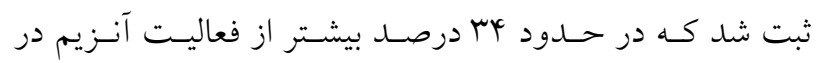

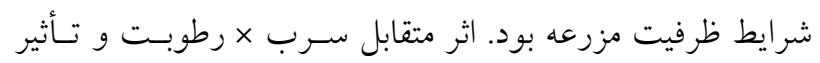

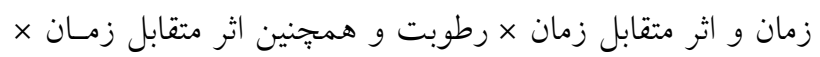

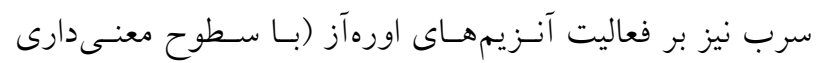

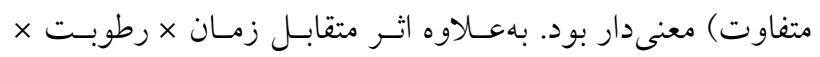
سرب در سطح احتمال يك درصد بر فعاليت آنزيمهـاى اورهآز

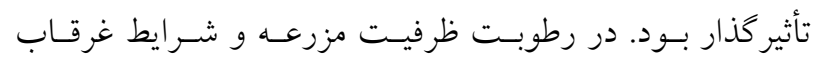

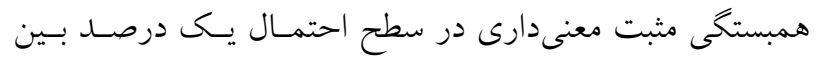

پايينى بود. ظرفيت تبادل كاتيونى خاك نيز در حد متوسط قـرار

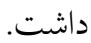

اثر سرب، رطوبت خاك و زمان بر فعاليت آنزيمهاى اورهآز

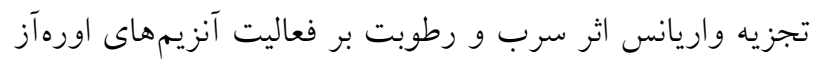
و فسفاتاز اسيدى و قليايى خاك در طى زمان در جدول ب ارائـه

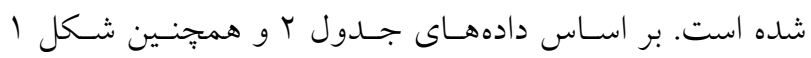

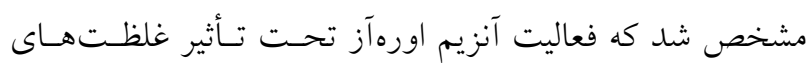

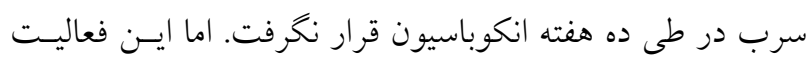
در تمامى سطوح سرب در رطوبت غرقاب بـهـور معنسى دارى

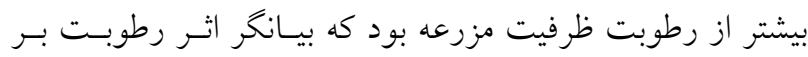

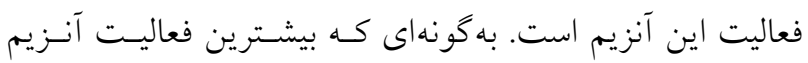

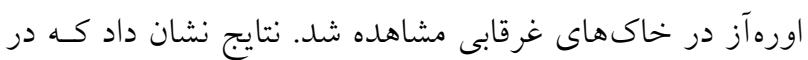



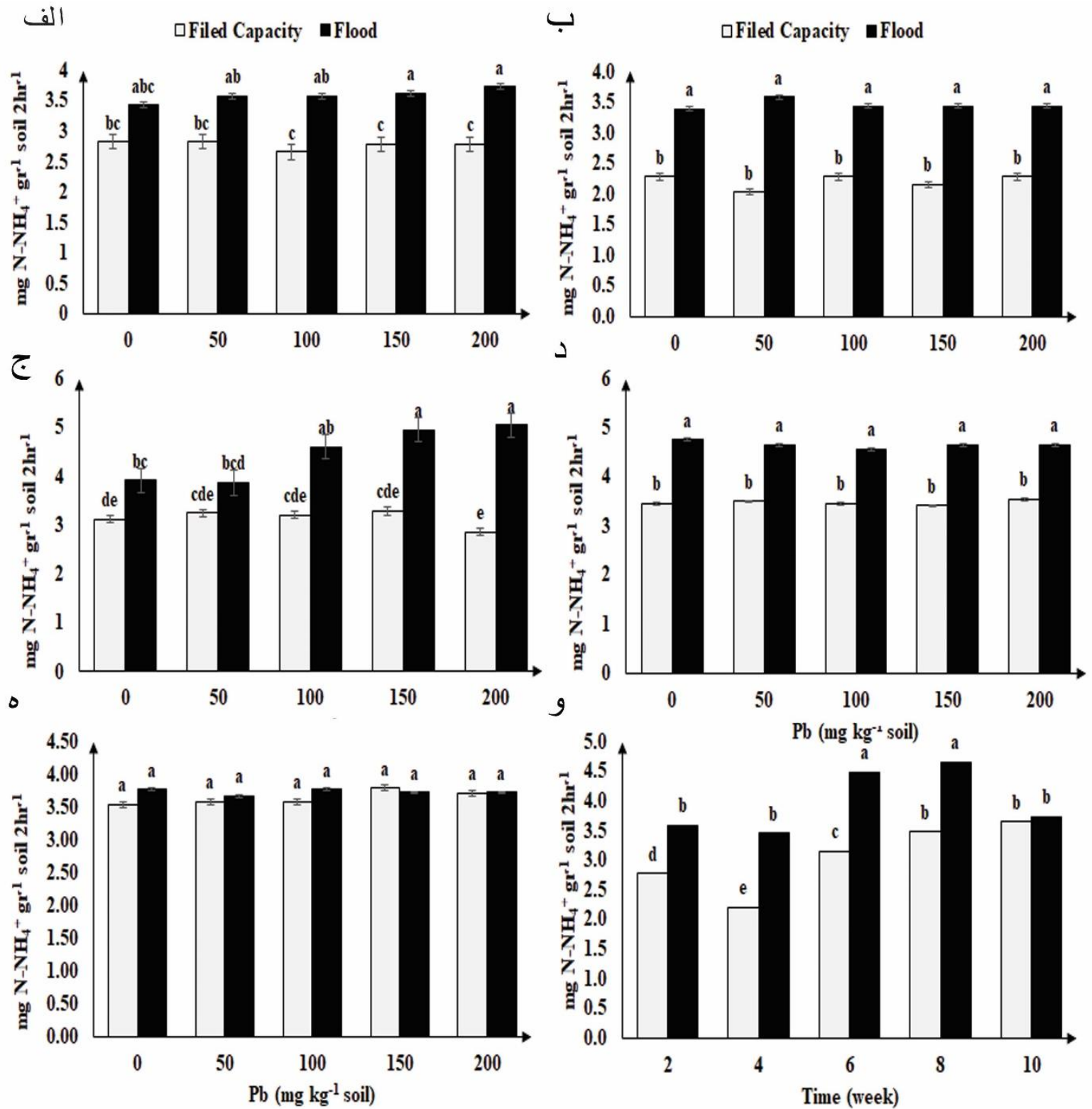

شكل (. تغيير ات فعاليت آنزيم اورهآز در طى: الف) دو، ب) جهار، ج) شش، د) هشت، ه) ده هفته انكوباسيون خاك در دو رزيم متفاوت

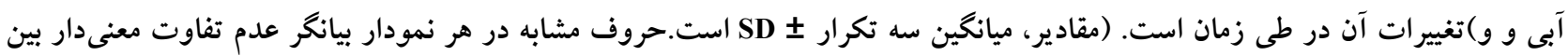

$$
\text { تيمارها با آزمون توكى در سطح ه درصد تهر است). }
$$

اثر سرب، رطوبت خاك و زمان بر فعاليت آنزيمهاى فسفاتاز

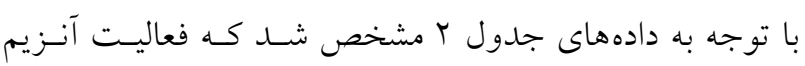

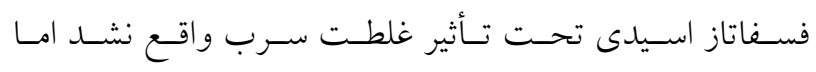

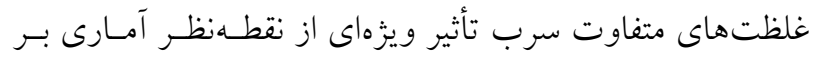

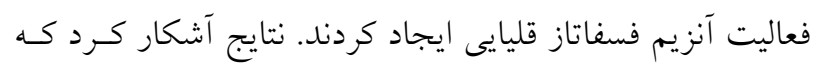

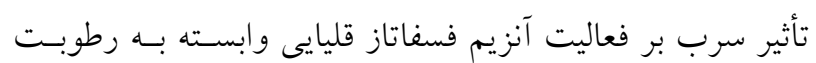

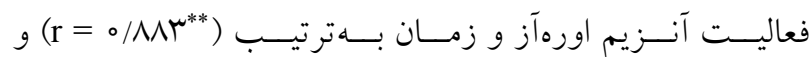

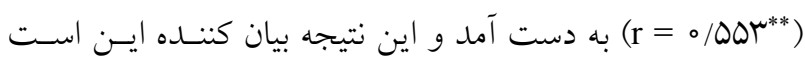

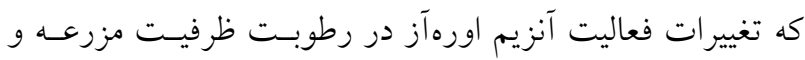

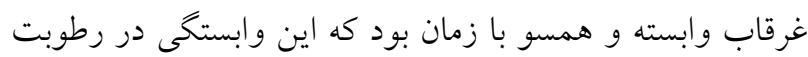

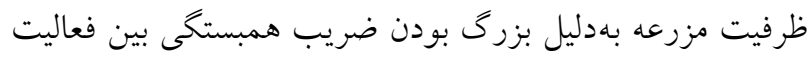
آنزيم اورهآز و زمان بيشتر بود. 
ششم بهترتيب تقريباً س و T/N برابر شده است و بـهـهورت كلى

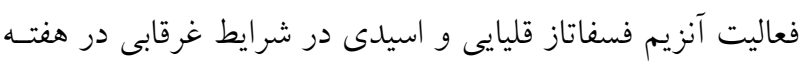

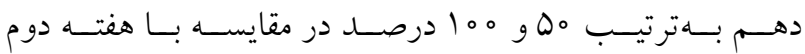

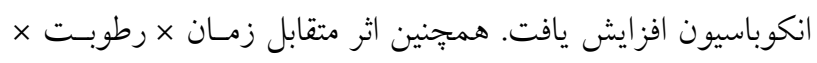

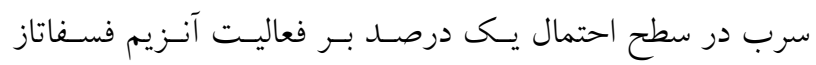
قليايى و در سطح احتمال ينج درصد بــر فعاليـت آنـزيم فسـفاتاز

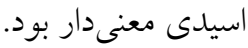

\section{بحث}

فلزات سنخين اثرات مضرى بر توابع بيولوزيكى خاك شامل انـازه،

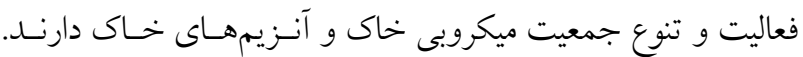

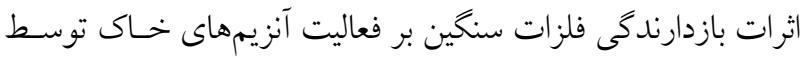

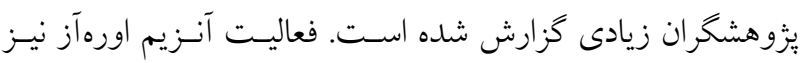

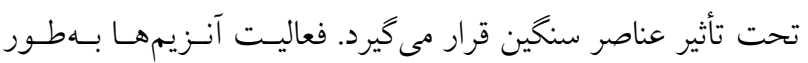

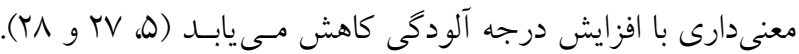

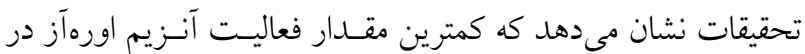

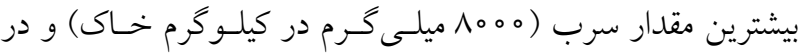

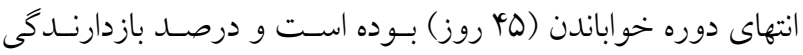

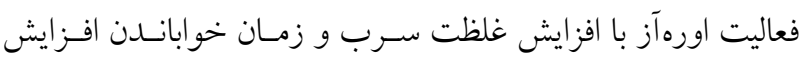

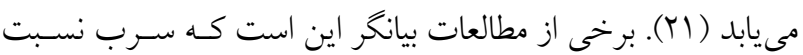

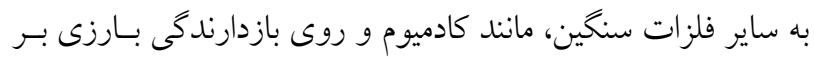

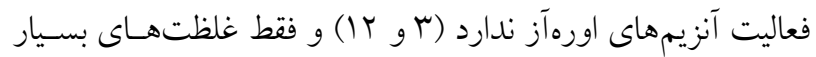

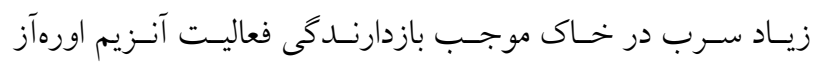

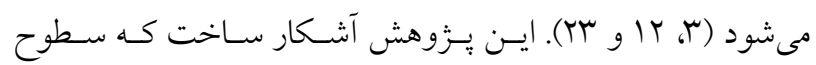
مختلف سرب اثر معنى دارى بر فعاليت آنزيم اورهآز نداشته و آنتزيم

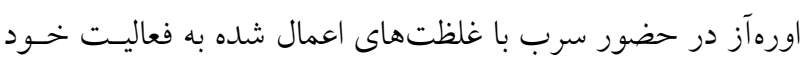

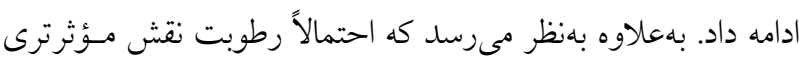

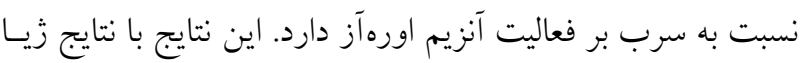

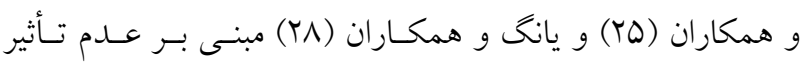

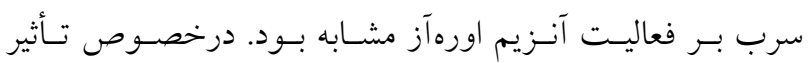

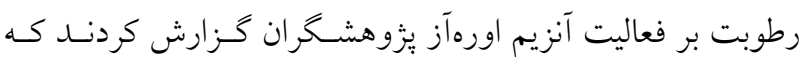

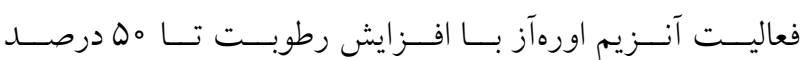

خاك است. بهطور كلى مشخص شـــ كـه در ظرفيـت مزرعـهـ بـاــا

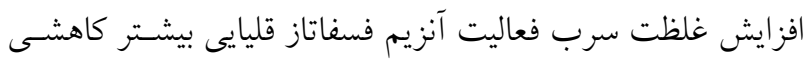

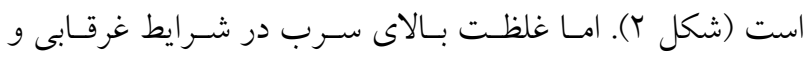
برهم كنش آن با عامـل رطوبـت سـبب افـز ايش فعاليـت فسـفاتاز

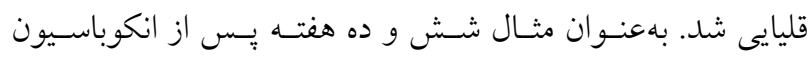

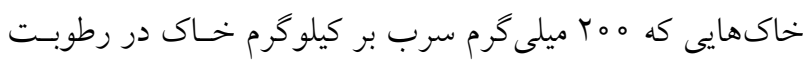

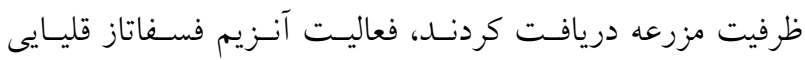
به ترتيب ها و وץ درصد در مقايسه با خاكهاى كنترل با رطوبت

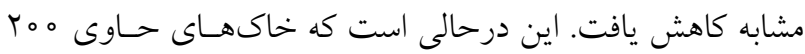
ميلى گرم سرب بر كيلو گرم خاك در شر ايط غرقابى در طـى زمـان

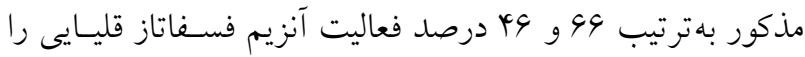
در مقايسه با خاكهاى كتترل بـا رطوبـت مشـابه افـزايش دادنـــ.

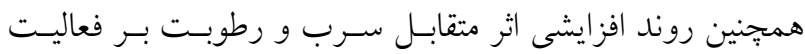

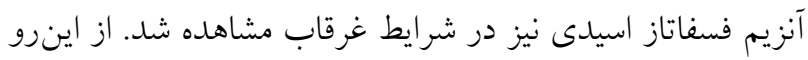

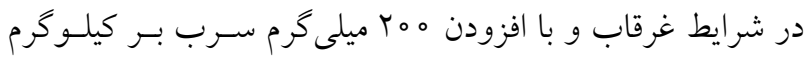

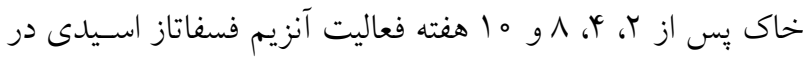

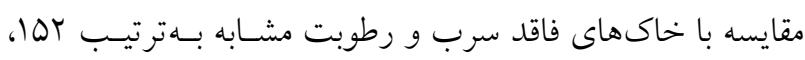

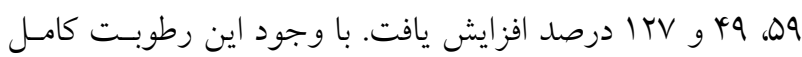

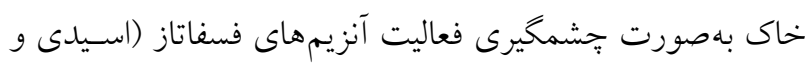

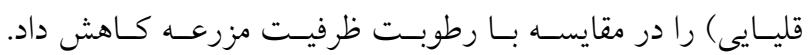
همانطور كه نتايج جدول انشان مىدهد فعاليت آنـزيم فسـفاتاز

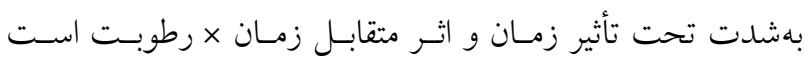

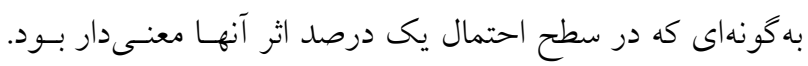

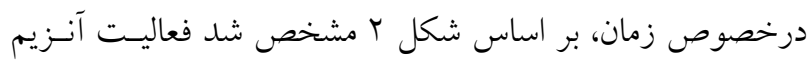
فسفاتاز اسيدى و قليايى در شرايط رطوبت مزرعـه متنـاوب بـود.

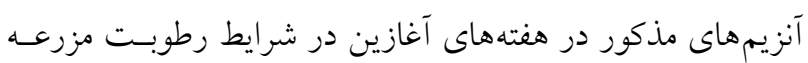

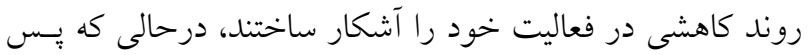

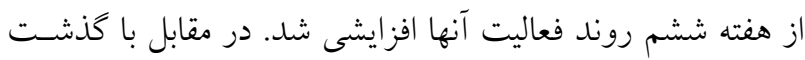

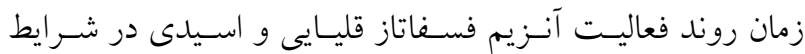

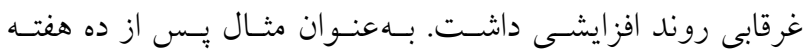

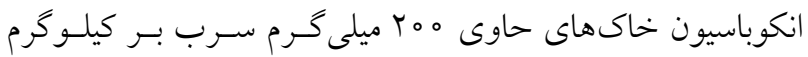

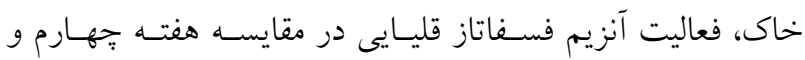



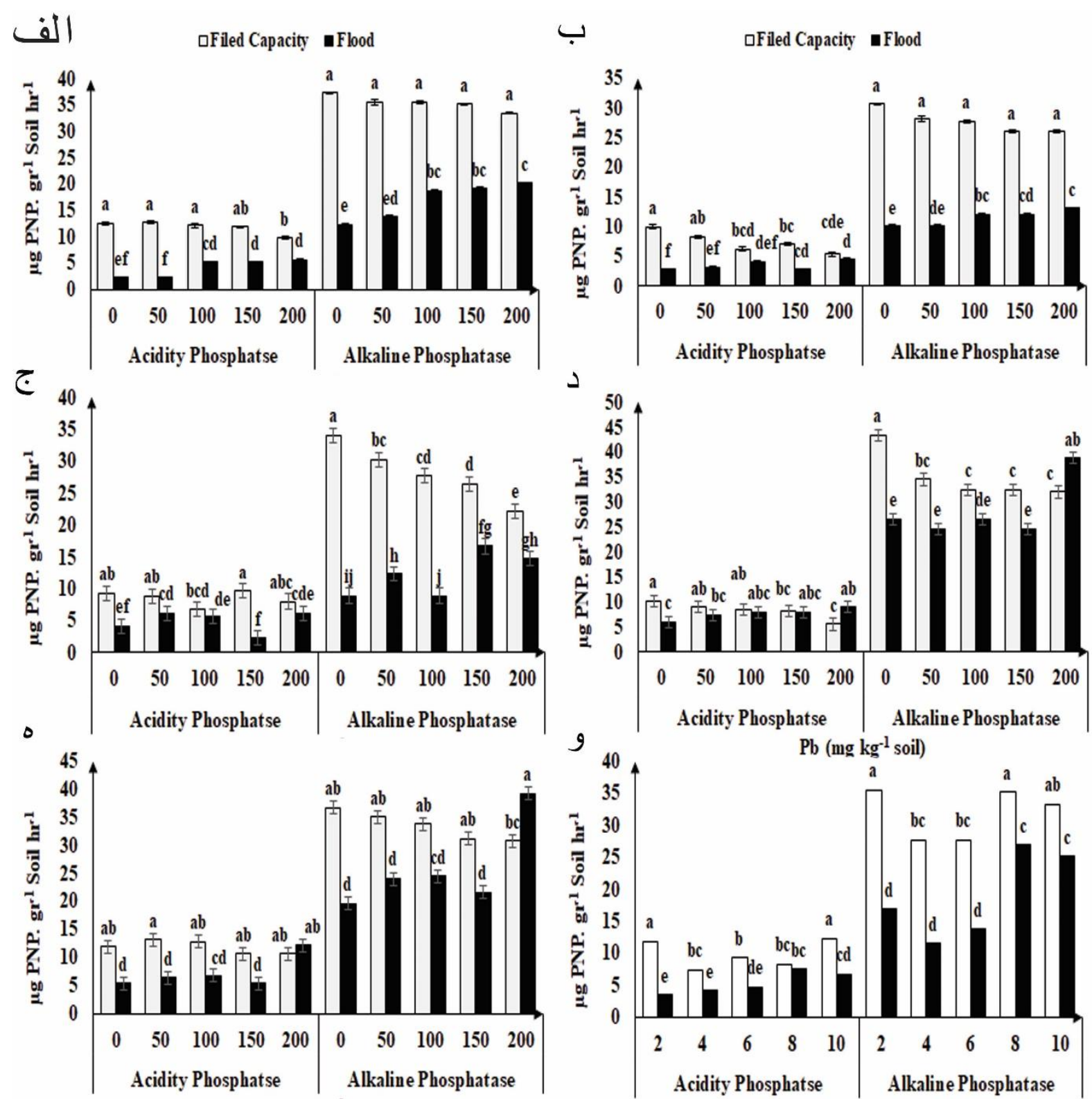

$\mathrm{Pb}\left(\mathrm{mg} \mathrm{kg}^{-1}\right.$ soil)

Time (week)

شكل r. تغييرات فعاليت آنزيمهاى فسفاتاز در طى: الف) دو، ب) جهار، ج) شش، د) هشت، ه) ده هفته انكوباسيون خاك در دو رزيم متفاوت آبى و و) تغييرات آن در طى زمان است (مقادير، ميانكين سه تكرار ISD است، حروف مشابه براى هر آنزيم (اسيدى و قليايى

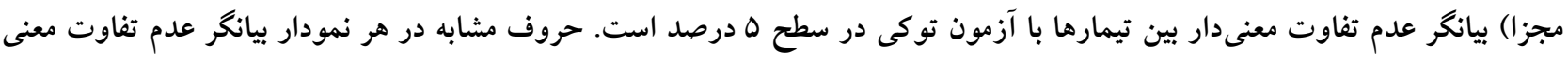

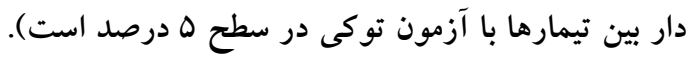

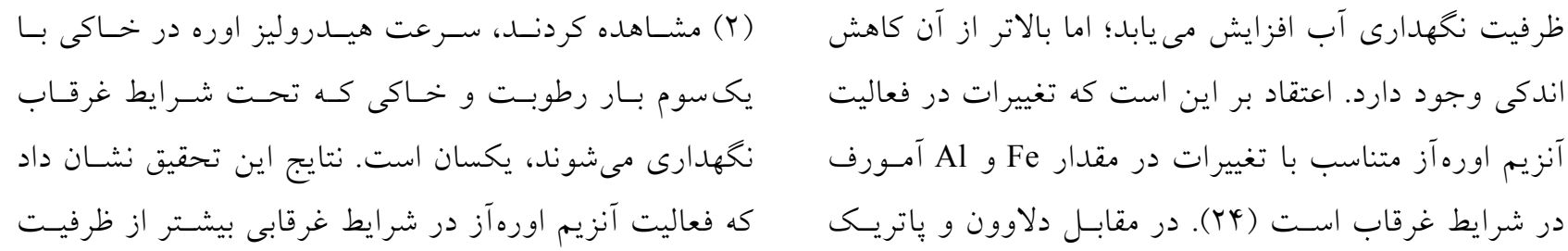


آنزيم فسفاتاز يك آنزيم برونسلولى است، لـــا فعاليـت آن

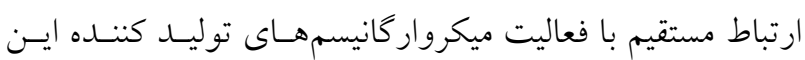

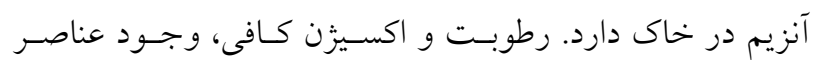

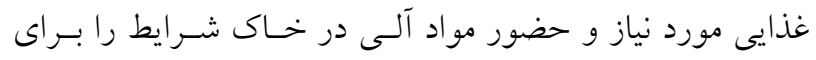

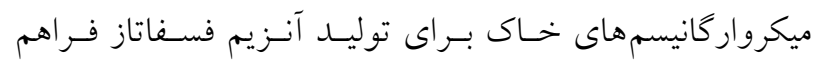

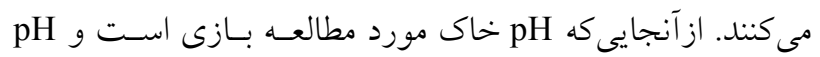

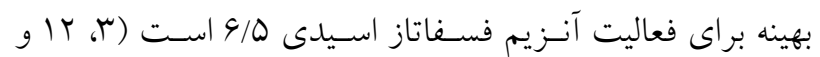

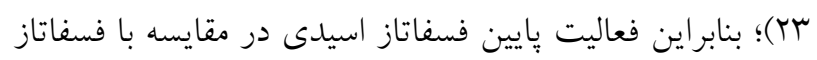

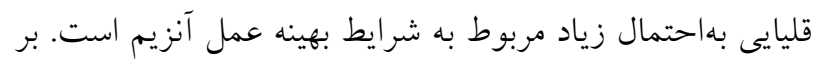

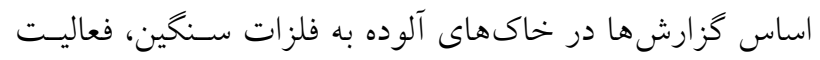

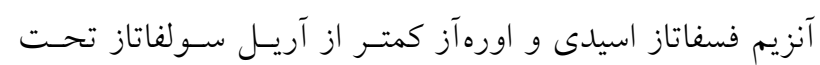

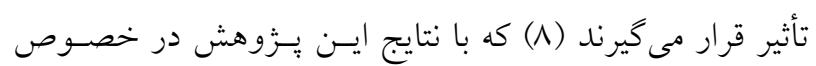

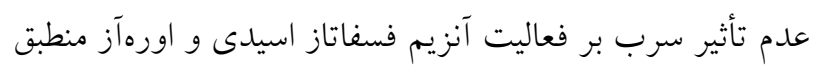

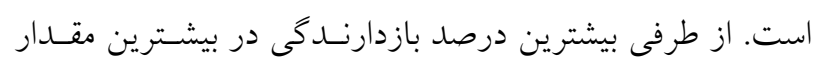

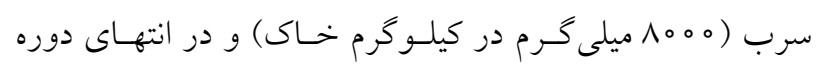

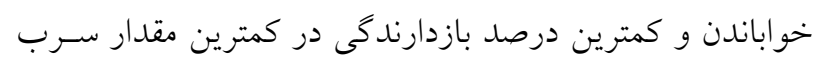

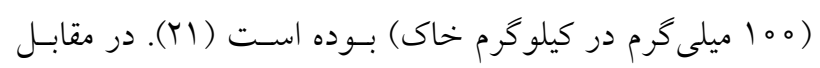

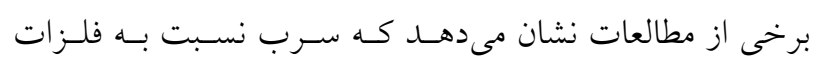

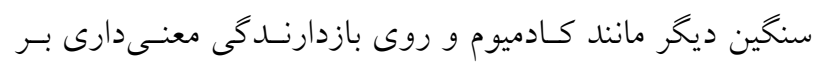

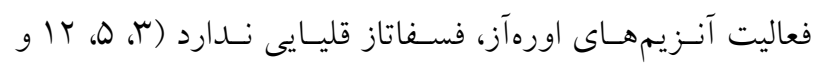

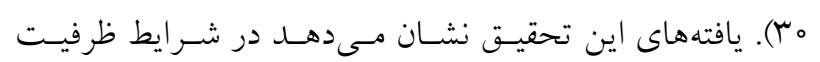

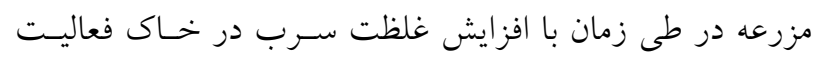

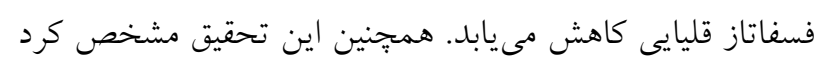
كه شرايط غرقابى سبب كاهش جشمخير فعاليت آنزيم فسـفاتاز

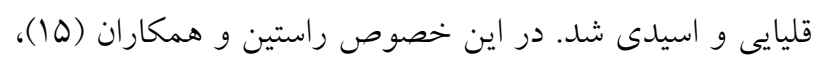

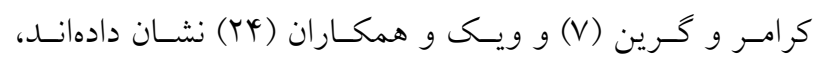

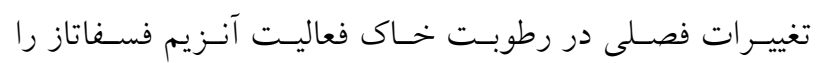

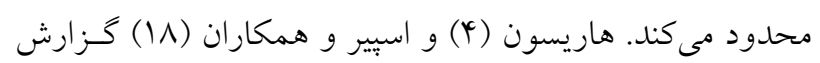

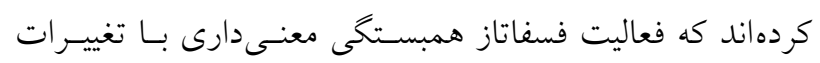

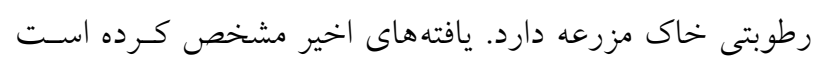

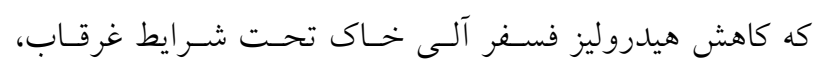

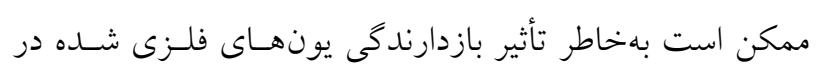

مزرعه است. همجنين روند فعاليت آنـزيم اورهآز در شـرايط

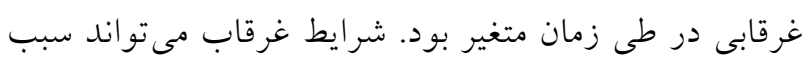

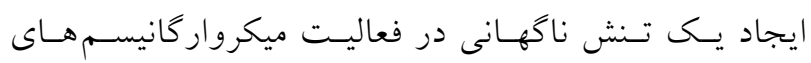

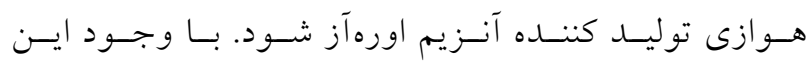

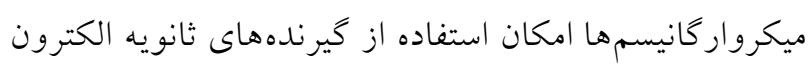

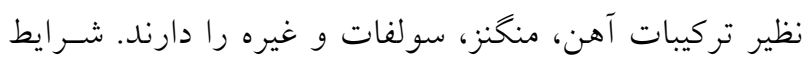

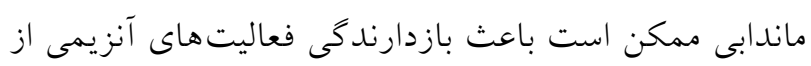

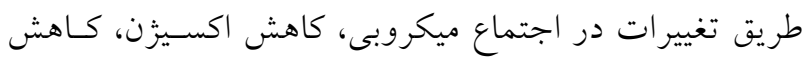

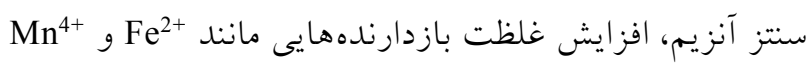

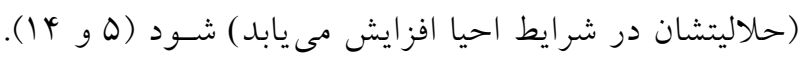

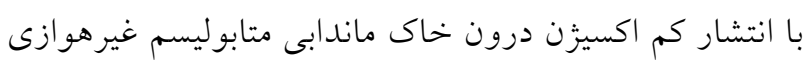

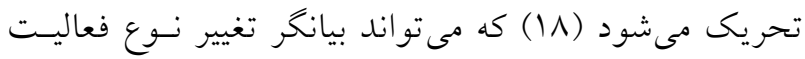

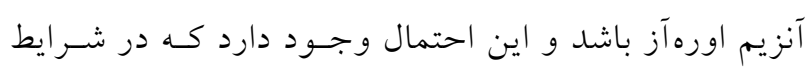

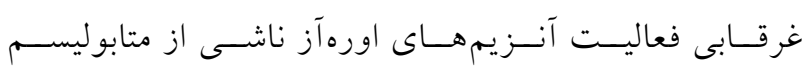

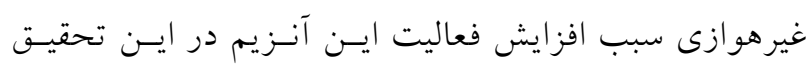

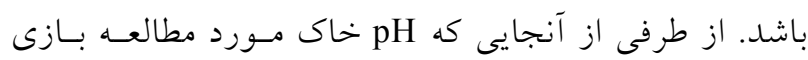

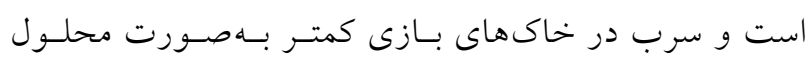

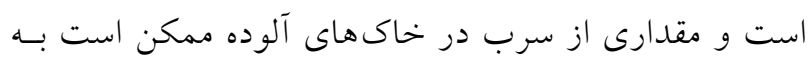

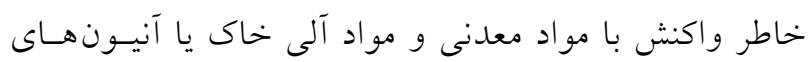

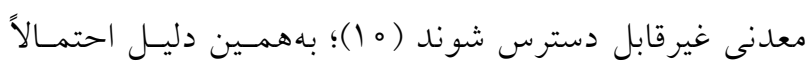

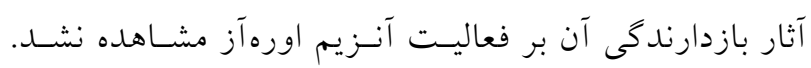

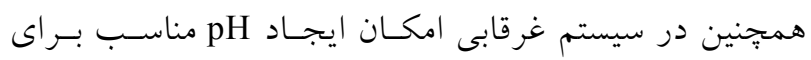

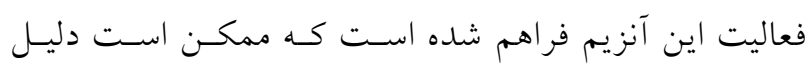

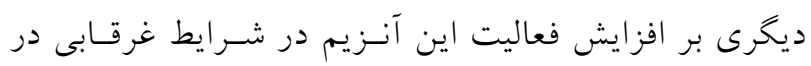

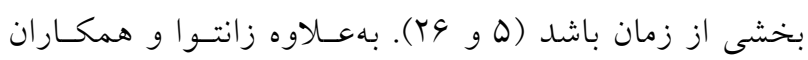

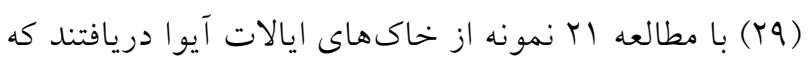

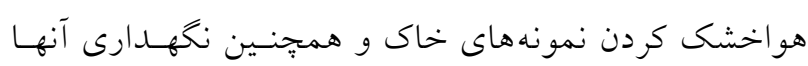

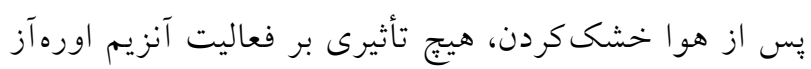

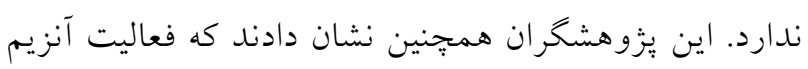

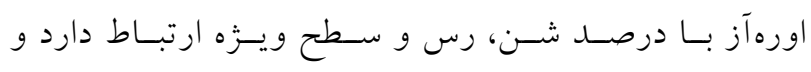

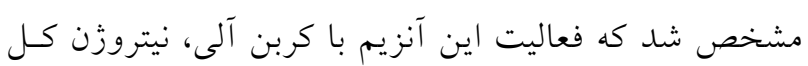

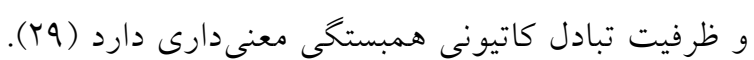




$$
\begin{aligned}
& \text { شرايط غرقاب بر فعاليت اين آنزيم اسـت (ه و ^). لـذا كـاهش آنزيم فسفاتاز احتمالاً مربوط به فراهمسى فسـفر معـدنى و آلى } \\
& \text { فعاليت آنزيمهاى فسـفاتاز در ايسن تحقيـق مسىتوانـد ناشسى از است كه نيازمند بررسى بيشترى است. مطالعات مشخص كـرده }
\end{aligned}
$$

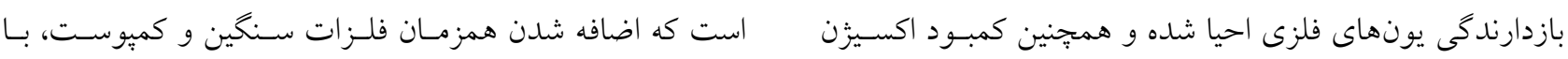

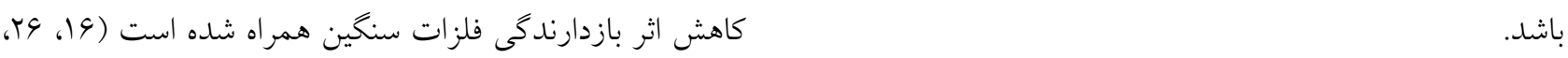

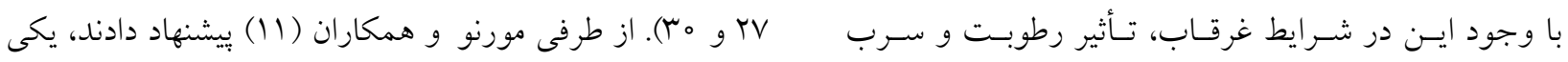

$$
\begin{aligned}
& \text { (برهم كنش آنها) در طى زمان سـبب افـزايش فعاليـت فسـفاتاز از دلايل كاهش فعاليت آنزيمى خاى با زمان خواباندن احتمـالاً }
\end{aligned}
$$

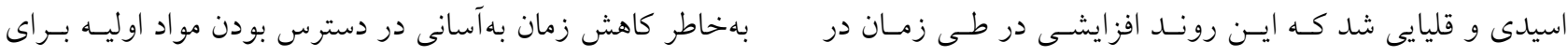

$$
\begin{aligned}
& \text { شرايط غرقابى درخصوص آنزيم فسفاتاز قليايى بيشـتر مشـهود ميكروار كانيسمهاى خاك است. لذا بـهنظـر مسىرسـد تغييـرات }
\end{aligned}
$$

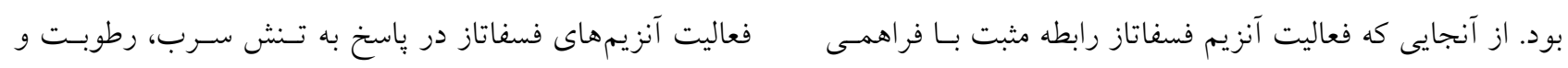

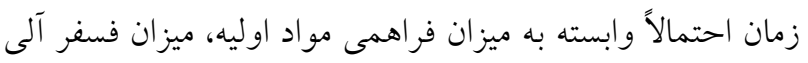

$$
\begin{aligned}
& \text { و است. pH } \\
& \text { فسفر آلى و رابطه منفى با فسـفر معـدنى در دسـترس دارد (ه). } \\
& \text { بنابر اين تأثير برهم كنش رطوبت و سـرب بــر تغييـرات فعاليـت }
\end{aligned}
$$

\section{منابع مورد استفاده}

1. Cao, H. -F., A. Chang and A. Page. 1984. Heavy metal contents of sludge-treated soils as determined by three extraction procedures 1. Journal of Environmental Quality 13: 632-634.

2. Delaune, R. and W. H. Patrick. 1970. Urea conversion to ammonia in waterlogged soils 1. Soil Science Society of America Journal 34: 603-607.

3. Eivazi, F. and M. Tabatabai. 1977. Phosphatases in soils. Soil Biology and Biochemistry 9: 167-172.

4. Harrison, A. 1983. Relationship between intensity of phosphatase activity and physico-chemical properties in woodland soils. Soil Biology and Biochemistry 15: 93-99.

5. Karaca, A., S. C. Cetin, O. C. Turgay and R. Kizilkaya. 2010. Effects of heavy metals on soil enzyme activities. PP. 237-262, Soil Heavy Metals. Springer.

6. Klute, A. and R. C. Dinauer. 1986. Physical and mineralogical methods. Planning 8: 79.

7. Krämer, S. and D. M. Green. 2000. Acid and alkaline phosphatase dynamics and their relationship to soil microclimate in a semiarid woodland. Soil Biology and Biochemistry 32: 179-188.

8. Maddela, N. R. and K. Venkateswarlu. 2018. Selected soils, insecticides and soil enzymes. PP. 17-31, InsecticidesSoil Microbiota Interactions. Springer.

9. Marzadori, C., C. Ciavatta, D. Montecchio and C. Gessa. 1996. Effects of lead pollution on different soil enzyme activities. Biology and Fertility of Soils 22: 53-58.

10. Modolo, L. V., C. J. da-Silva, D. S. Brandão and I. S. Chaves. 2018. A minireview on what we have learned about urease inhibitors of agricultural interest since mid-2000s. Journal of Advanced Research 13: 29-37.

11. Moreno, J., T. Hernández and C. Garcia. 1999. Effects of a cadmium-contaminated sewage sludge compost on dynamics of organic matter and microbial activity in an arid soil. Biology and Fertility of Soils 28: 230-237.

12. Nannipieri, P., L. Giagnoni, L. Landi and G. Renella. 2011. Role of phosphatase enzymes in soil. PP. 215-243. In: Bünemann, E., A. Oberson and E. Frossard, (Eds.), Phosphorus in Action: Biological Processes in Soil Phosphorus Cycling. Springer Berlin Heidelberg, Berlin, Heidelberg.

13. Page, A., R. Miller and D. Keeney. 1982. Methods of soil analysis. Part 2. Chemical and Microbiological Properties. American Society of Agronomy. Soil Science Society of America.

14. Pierzynski, G., J. Sims and G. Vance. 2000. Soils and Environmental Quality, CRC Press LLC. Boca Raton, FL.

15. Rastin, N., K. Rosenplänter and A. Hüttermann. 1988. Seasonal variation of enzyme activity and their dependence on certain soil factors in a beech forest soil. Soil Biology and Biochemistry 20: 637-642.

16. Salam, A. K., Y. Desvia, E. Sutanto, T. Syam, S. G. Nugroho and M. Kimura. 1999. Activities of soil enzymes in different land-use systems in middle terrace areas of Lampung Province, South Sumatra, Indonesia. Soil Science and Plant Nutrition 45: 89-99.

17. Sparks, D. L., P. Helmke and A. Page. 1996. Methods of soil analysis: Chemical Methods. SSSA.

18. Speir, T. W., H. Kettles, A. Parshotam, P. Searle and L. Vlaar. 1995. A simple kinetic approach to derive the 
ecological dose value, ED50, for the assessment of Cr (VI) toxicity to soil biological properties. Soil Biology and Biochemistry 27: 801-810.

19. Tabatabai, M. 1982. Soil enzymes1. Methods of Soil Analysis. Part 2. PP. 903-947, Chemical and Microbiological Properties, Madison.

20. Tabatabai, M. and J. Bremner. 1969. Use of p-nitrophenyl phosphate for assay of soil phosphatase activity. Soil Biology and Biochemistry 1: 301-307.

21. Tejada, M., M. Hernandez and C. Garcia. 2007. Application of two organic wastes in a soil polluted by lead. Journal of Environmental Quality 36: 216-225.

22. Walkley, A. 1947. A critical examination of a rapid method for determining organic carbon in soils-effect of variations in digestion conditions and of inorganic soil constituents. Soil Science 63: 251-264.

23. Wang, L., W. Zhang, J. Wang, L. Zhu, J. Wang, S. Yan and Z. Ahmad. 2019. Toxicity of enrofloxacin and Cadmium alone and in combination to enzymatic activities and microbial community structure in soil. Environmental Geochemistry and Health 1-14.

24. Wick, B., R. F. Kühne, K. Vielhauer and P. L. Vlek. 2002. Temporal variability of selected soil microbiological and biochemical indicators under different soil quality conditions in south-western Nigeria. Biology and Fertility of Soils 35: 155-167.

25. Xia, L., L. Shuqing and W. Shengai. 2002. The relationship between heavy metal forms and soil enzymatic activities in the main soils of Hebei Province. Hebei Nongye Daxue Xuebao (China) 25: 33-37.

26. Xian, Y., M. Wang and W. Chen. 2015. Quantitative assessment on soil enzyme activities of heavy metal contaminated soils with various soil properties. Chemosphere 139: 604-608.

27. Yang, X., J. Liu, K. McGrouther, H. Huang, K. Lu, X. Guo, L. He, X. Lin, L. Che and Z. Ye. 2016. Effect of biochar on the extractability of heavy metals $(\mathrm{Cd}, \mathrm{Cu}, \mathrm{Pb}$, and $\mathrm{Zn})$ and enzyme activity in soil. Environmental Science and Pollution Research 23: 974-984.

28. Yang, Z. -X., S. -Q. Liu, D. -W. Zheng and S.-D. Feng. 2006. Effects of Cadium, Zinc and Lead on soil enzyme activities. Journal of Environmental Sciences 18: 1135-1141.

29. Zantua, M., L. Dumenil and J. Bremner. 1977. Relationships between soil urease activity and other soil properties 1. Soil Science Society of America Journal 41: 350-352.

30. Zhang, Y., L. Chen, X. Chen, M. Tan, Z. Duan, Z. Wu, X. Li and X. Fan. 2015. Response of soil enzyme activity to long-term restoration of desertified land. Catena 133: 64-70. 


\title{
The Relationship between Soil Moisture and Lead on the Activity of Urease and Phosphatase Enzymes
}

\author{
A. Forghani ${ }^{*}$, A. H. Forghani ${ }^{2}$, M. Taghizadeh ${ }^{3}$ and B. Rabiei ${ }^{3}$
}

(Received: January 7-2019; Accepted: July 22-2019)

\begin{abstract}
Soils pollution with heavy metals is due to the presence of various metals such as copper, nickel, cadmium, zinc, chromium and lead. Heavy metals have a negative effect on the biological parameters of soil, including size, activity and diversity of soil microbial population, as well as the enzymes involved in the deformation of such elements as P, N, $\mathrm{C}$, and S. Thus, the activity of soil enzymes as a bioavailable agent is reflected as a cheap and fast method for the natural and anthropogenic distribution of heavy metals contamination. The purpose of this study was to investigate the effect of lead, humidity and their interaction on urease and phosphatase enzyme activity during a 10 week incubation period. Different levels of acetate lead (50,100, 150 and $200 \mathrm{mg} / \mathrm{kg}$ soil) were added to the plots containing two different moisture regimes (field capacity and flooding). The activity of urease and phosphatase (alkaline and acidity) was measured after 2,4,6,8 and 10 weeks of incubation. The results indicated different levels of lead had no significant effect on the activity of urease and acidity phosphatase. In contrast, high levels of lead significantly reduced the activity of alkaline phosphatase. Moreover, moisture served a different role in the activity of these enzymes, and it was related to the lead concentration and incubation time. Additionally, the function and interaction of lead, moisture and time were very influential on urease and phosphatase activity. Therefore, the above three characteristics are very important to study soil contamination for the polluted soils.
\end{abstract}

Keywords: Field capacity, Flood, Acid phosphatase, Alkaline phosphatase, Physical and chemical of soil

1- Department of Soil Science, College of Agriculture Science, University of Guilan, Guilan, Iran.

2- Department of Biology, College of Science, Payame Noor University, Tehran, Iran.

3- Department of Agronomy and Plant Breeding, College of Agriculture Science, University of Guilan, Guilan, Iran.

*: Corresponding author, Email: forghani@guilan.ac.ir 